\title{
FOLLY TO THE GREEKS: GOOD REASONS TO GIVE UP REASON
}

\author{
STEPHEN R. L. CLARK \\ University of Liverpool
}

\begin{abstract}
Good reasons to "give up reason" are (i) naturalistic reasons that downplay the likely effectiveness of human mentation - these lead to contradiction if naturalism itself is reckoned "really true"; (ii) there are pragmatic reasons to license and enjoy imaginative stories that conflict with principles elevated as "rational"; (iii) mystical reasons, which take account of the revolutionary aspects of certain "religious" disciplines, and throw doubt on what we "naturally" take for granted.
\end{abstract}

\section{THESIS: RATIONAL RELIGION}

On past occasions I've argued that both the content of commonsensical reasoning and the methods and axioms that we identify with "reason" or "scientific reason" are themselves accepted "on faith", though we may call it "intuition" or "intellect". I have also suggested that this faith is at least more "reasonable", or consistent, when couched in theistic terms. So far from theism being at odds with "science", science, both historically and logically, gives some support to theism: at least the apparent success of science is better explained, and more expectable, on a theistic account than on a naturalistic. The words that David Hume invented for Philo have a wider impact than is usually acknowledged: "what peculiar privilege has this little agitation of the brain which we call 'thought' that we must thus make it the model of the whole universe?" 1 What indeed? Why should we suppose that the patterns we discern are ones that the

\footnotetext{
${ }^{1}$ David Hume, Dialogues Concerning Natural Religion (1779), part 2.
} 
whole universe obeys? We recognize that we have the sensory organs and modalities we do because these were the ones that helped our ancestors survive and procreate, and that other creatures, for equivalent reasons, sense things differently. Why should our intellectual gifts be any better fitted to an understanding of worlds and ages far away? What has been called the unreasonable effectiveness of mathematics ${ }^{2}$ is a sort of confirmation that we have the root of the matter in us, that our intellect is a spark of the universal reason, an image of the God on whom everything depends. ${ }^{3}$ Or else, of course, we should rather abandon that conviction, and with it any confidence that mathematics is more than a sometimes useful fiction. The "success" of science can only be pragmatic, parochial, transient, and we have no reason to extrapolate the patterns that we happen to see here-now to a wider world. Nor can we reasonably suppose both that there are no universal binding obligations (that is, that there is no God) and also that there is a universal binding obligation to pursue "the truth". If atheistical naturalists are correct we cannot reasonably expect to discover truths beyond, at best, the parochial, nor do we have any obligation to try. Most creatures, as Plotinus pointed out, manage quite well without reasoning ${ }^{4}$, and so do most people. Conversely, if we can and should pursue and prefer the truth, then a form of theism is, essentially, correct.

I don't wish to withdraw these claims. My belief is that we can rely on "reason", even though we should also acknowledge that it is often obscured by ignorance, stupidity, self-conceit, wishful thinking, malice and all other sorts of sin. The principal dogmas of mainstream Abrahamic theism provide a proper context for that cautious confidence. There is a single source for all things; this source is expressed in the Logos, and the Logos is, at least, available to us. This does not constitute a "proof" of those dogmas - I doubt if there are ever any final or conclusive or universally persuasive proofs of anything - but atheistical naturalists are

${ }^{2}$ Eugen Wigner, "The Unreasonable Effectiveness of Mathematics in the Natural Sciences" in Communications in Pure and Applied Mathematics, 13 (1960), pp. 1-14.

${ }^{3}$ So also Benedict XVI (2009): 'the objective structure of the universe and the intellectual structure of the human being coincide; the subjective reason and the objectified reason in nature are identical. In the end it is "one" reason that links both and invites us to look to a unique creative Intelligence': URL $=<$ http://www.vatican. va/holy_father/benedict_xvi/messages/pont-messages/2009/documents/hf_ben-xvi_ mes_20091126_fisichella-telescopio_en.html> (accessed 29th April 2011).

${ }^{4}$ Plotinus, Ennead, I.4 [46].2, pp. 31-43. 
at least condemned to a more incoherent doctrine than are theists, as they must believe simultaneously that creatures like us are unlikely to be equipped to understand the cosmos, and that they themselves know enough to know that theism is mistaken.

Chesterton was almost right to say that "all sane men ... believe firmly and unalterably in a certain number of things which are unproved and unprovable". He listed them as follows:

Every sane man believes that the world around him and the people in it are real, and not his own delusion or dream. No man starts burning London in the belief that his servant will soon wake him for breakfast. But that I, at any given moment, am not in a dream, is unproved and unprovable. That anything exists except myself is unproved and unprovable.

All sane men believe that this world not only exists, but matters. Every man believes there is a sort of obligation on us to interest ourselves in this vision or panorama of life. He would think a man wrong who said, "I did not ask for this farce and it bores me. I am aware that an old lady is being murdered down-stairs, but I am going to sleep." That there is any such duty to improve the things we did not make is a thing unproved and unprovable.

All sane men believe that there is such a thing as a self, or ego, which is continuous. There is no inch of my brain matter the same as it was ten years ago. But if I have saved a man in battle ten years ago, I am proud; if I have run away, I am ashamed. That there is such a paramount " $\mathrm{I}$ " is unproved and unprovable. But it is more than unproved and unprovable; it is definitely disputed by many metaphysicians.

Lastly, most sane men believe, and all sane men in practice assume, that they have a power of choice and responsibility for action. ${ }^{5}$

Like Chesterton, I think that these fundamental principles - however I might also seek to qualify them - are necessary for our sanity and the civil peace, and that they are easier (psychologically and logically) for theists to maintain. In brief, "reason" and "faith" are compatible: there is nothing unreasonable about taking some things "on faith" (for we

${ }^{5}$ G.K. Chesterton, Daily News, June 22, 1907: a reference I owe to Martin Ward, and his collection of Chesterton texts: URL $=<$ http://www.gkc.org.uk/gkc/ $>$ (accessed 29 ${ }^{\text {th }}$ April 2011). See also Edward Herbert, De Veritate, tr. M.H. Carré (Bristol: Arrowsmith, 1937), p. 83: "Truth exists: the sole purpose of this proposition is to assert the existence of truth against imbeciles and sceptics." 
must if we are ever to reason at all), and nothing amiss in principle with mainstream theistic doctrines (for they make it easier to believe in reason). But I shall now proceed to present what I take to be good reasons not to be ruled by reason.

But first I should explain more clearly what I take "reason" to be. Considered simply as a spark of the divine, "reason" must stand for our recognition of beauty, truth and holiness, whereby we also acknowledge our own dependence, failures, fallibility. Lovejoy's analysis is more abstract than Chesterton's, but just as valuable.

The primary and most universal faith of man [is] his inexpugnable realism, his twofold belief that he is on the one hand in the midst of realities which are not himself nor mere obsequious shadows of himself, a world which transcends the narrow confines of his own transient being; and on the other hand that he can himself somehow read beyond those confines and bring those external existences within the compass of his own life yet without annulment of their transcendence. ${ }^{6}$

Richard Rorty's declaration that this faith is absurd ${ }^{7}$ is no more coherent than any similarly Protagorean creed: obviously, Rorty wishes to say that Lovejoy was simply wrong to believe that there were truths we did not and do not engineer and yet can partly grasp, but he can only manage this rebuttal if indeed there are. But however silly Rorty's claim may be it does confirm my first assertion: those who won't believe in God may easily end up not believing in reason or the truth. What then stands in for "reason" in the older, higher sense? What guddle of capacities, beliefs and habits should we call "reasoning", if we are to start from a non-theistic position? What counts as "reason" if we put aside the older notion that it is a spark of the divine, a willed commitment to beauty, truth and goodness?

Commonsensically, people are judged "rational" when they set aside any personal, peculiar, subjective feelings about their situation, so as to think and act as they could advise just anyone to think and act. They are judged "rational" when they take account of the likely effects of what they do before responding carelessly in rage or lust or fear. They are "rational" if they manage not to contradict themselves too often, do not endorse any very novel thesis until there is "evidence" for it, and stand ready to abandon older certainties - when they think it right. "Rational" people distinguish dreams from waking, are suspicious of whatever sounds

\footnotetext{
${ }^{6}$ A. O. Lovejoy, The Revolt Against Dualism (La Salle, Illinois: Open Court, 1930), p. 14.
}

${ }^{7}$ R. M. Rorty, Philosophy and the Mirror of Nature (Oxford: Blackwell, 1980), p. 52n. 
"too good to be true", and usually prefer to do and think only what has been done and thought before. "Rational" people are mildly suspicious of what gurus, self-styled experts, dictators and most politicians say, but also hesitate before accepting what is said by anonymous critics of the establishment. Sometimes these rough rules of thumb are elevated to more general principles, and begin to sound absurd. Clifford's Rule, for notorious example, that one should never believe anything without sufficient evidence, is both vague, self-refuting (since there is no unquestionable evidence for this strategy) and impractical, since we are doomed always to be acting on inadequate information. ${ }^{8}$ Indeed it is difficult to see how we could ever get experimental or theoretical or even anecdotal "proof" of anything without accepting it as at least a working hypothesis long before there was "proof" - and such acceptance has its costs, which are only cheerfully endured by those who "believe", in advance of evidence, that the search will be worthwhile. Nor is it always sensible, or honourable, to disregard our personal feelings, and peculiar loyalties, when deciding who or what to believe. At any rate perennial sceptics and disloyal partners (quick to disbelieve their significant other's protests unless just anyone would "have to believe them now") are not well-regarded. Nor need they be less often deceived by life than are more trusting, loving agents.

Clifford's further conviction was that "we may go beyond experience by assuming that what we do not know is like what we do know; or, in other words, we may add to our experience on the assumption of a uniformity in nature." But this assumption is notoriously ill-formed. The problem is not only that it is itself ungrounded (and implausible), but that we cannot even identify what to extrapolate from our present experience. Nelson Goodman's "second problem of induction" was anticipated by Charles Babbage, one of the founding fathers of the computer age. In 1833, he tells us, he put together a small portion of the calculating engine he had devised, the Difference Engine, and started it. ${ }^{9}$ It conscientiously progressed from 1 to 2 to 3 to every number up to

\footnotetext{
${ }^{8}$ See W.K. Clifford, 'The Ethics of Belief' (1877), in Lectures and Essays, eds., L. Stephen \& F. Pollock (Macmillan: London 1879), vol.2, pp. 163ff. Cf. William James, The Will to Believe (New York: Longmans, Green \& Co., 1897), p. 30: "if we believe that no bell tolls in us to let us know for certain when truth is in our grasp, then it seems a piece of idle fantasticality to preach so solemnly our duty of waiting for the bell."

${ }^{9}$ Charles Babbage, The Ninth Bridgwater Treatise: a Fragment (London, 1838; reissued by Frank Cass: London, 1967), pp. 186ff. The treatise is so called not because
} 
$100,000,001$. The obvious inference was that it would continue adding 1 to each succeeding number - yet the numbers that followed were $100,010,002 ; 100,030,003 ; 100,060,004 ; 100,100,005 ; 100,150,006$ "and so on" until the $2672^{\text {nd }}$ term, when the rule seemed to change again (and yet again after 1430 terms, and again after 950 , and so on $)^{10}$.

Now it must be remarked, that the law that each number presented by the Engine is greater by unity than the preceding number, which law the observer had deduced from an induction of a hundred million instances, was not the true law that regulated its action; and that the occurrence of the number 100,010,002 at the 100,000,002d term was as necessary a consequence of the original adjustment, and might have been as fully foreknown at the commencement, as was the regular succession of any one of the intermediate numbers to its immediate antecedent. The same remark applies to the next apparent deviation from the new law, which was founded on an induction of 2761 terms, and to all the succeeding laws; with this limitation only that whilst their consecutive introduction at various definite intervals is a necessary consequence of the mechanical structure of the engine, our knowledge of analysis does not yet enable us to predict the periods at which the more distant laws will be introduced. ${ }^{11}$

A less alert investigator, of course, might simply have concluded that the engine was defective. The problem is that any engine, any predictive device, may have some similar "defect", even if this isn't manifest within our limited experience. We cannot know what is meant when we speak even of such simple things as acorns, cats or children, since we cannot know what even such things would be or will be under different conditions, nor what property it is that we are to extrapolate.

But though the principles of abstract reason (never to accept a contradiction; never to believe without "sufficient" evidence; always to discount one's own position, feelings and inchoate intuitions, while at the same time assuming that the world outside our experience is just like the world within, and so on) aren't helpful as absolute rules, we may continue commonsensically to think that we can tell the "rational" from the "irrational", the ignorant or insane. We cannot, practically speaking, live like "rationalists" of the stricter sort, but we may often find it wise to

Babbage had written eight earlier ones, but because it was an uncanonical addition to the eight Bridgwater Treatises composed by other leading $19^{\text {th }}$ century thinkers.

${ }^{10}$ Ibid., pp. 34ff.

${ }^{11}$ Ibid., pp. $38 f$. 
suspend judgement upon many things, or at least not leap too quickly to conclusions. Whether this caution will prevail, who knows?

This pragmatic, commonsensical approach to "reasoning" is compatible even with those "animistic" habits of mind that modern atheists despise: imagining ourselves into the life of stars, clouds, trees or engines may make it easier to live with them, and even easier to predict their actions. But we may still feel that "right reason" requires a commitment to a universal truth, and to disown error. That ascetic demand, to purge ourselves of error even when that error is very useful, has a theological origin. Thomas Sprat, in his history of the Royal Society, borrowed ideas from Athanasius to promote his "experimentalist" creed:

The poets of old to make all things look more venerable than they were devised a thousand false Chimaeras; on every Field, River, Grove and Cave they bestowed a Fantasm of their own making: With these they amazed the world ... And in the modern Ages these Fantastical Forms were reviv'd and possessed Christendom. ... All which abuses if those acute Philosophers did not promote, yet they were never able to overcome; nay, not even so much as King Oberon and his invisible Army. But from the time in which the Real Philosophy has appear'd there is scarce any whisper remaining of such horrors ... The course of things goes quietly along, in its own true channel of Natural Causes and Effects. For this we are beholden to Experiments; which though they have not yet completed the discovery of the true world, yet they have already vanquished those wild inhabitants of the false world, that us'd to astonish the minds of men. ${ }^{12}$

To live as theists of this "rational" kind is to act on the assumption that there is a truth that we can partly learn (and should) by following an ascetic path, purging ourselves of idolatry. The obligation also requires

12 Thomas Sprat, (History of the Royal Society 1702, p. 340) against fairies (cited by Basil Wiley, The Seventeenth Century Background (London: Chatto \& Windus, 1934), p. 213.) Sprat borrowed his imagery from See St. Athanasius, On the Incarnation (written c. $318 \mathrm{AD}$ ), op.cit., ch. 8, para. 47: "In former times every place was full of the fraud of oracles, and the utterances of those at Delphi and Dodona and in Boeotia and Lycia and Libya and Egypt and those of the Kabiri and the Pythoness were considered marvellous by the minds of men. But now since Christ has been proclaimed everywhere, their madness too has ceased, and there is no one left among them to give oracles at all. Then, too, demons used to deceive men's minds by taking up their abode in springs or rivers or trees or stones and imposing upon simple people by their frauds. But now, since the Divine appearing of the Word, all this fantasy has ceased, for by the sign of the cross, if a man will but use it, he drives out their deceits." 
us to cooperate with others: a truth that is only mine is not a truth worth having, and one that is also "ours" must be approached together. Some philosophical theists may end there, with a purely "rational religion", one that can be made plausible to "just anyone" willing to enquire into the grounds of scientific discovery. But "rational religion" is perhaps more vulnerable than its advocates desire. Once it is agreed that it is down to "us" to judge religious belief and practice, and to do so by appeal to presently commonsensical beliefs, the content of traditional belief may be gradually eroded, or made to sound less plausible. Does the minimal, rational theism I have so far defended do much more than agree that there is an intelligible world whose nature is also partly present in its parts? Each bit of the world, including our own mentality, embodies universal principles. If it were not so, it seems, there would be no world to understand, nor any living creature to understand it. What need of further ritual or elaborate story? What need of pious imagination? How does rational religion differ from an elementary, largely pragmatic, moralism about the importance of social exchanges and a less prejudicial outlook? Surely religion as ordinarily understood is more exciting, and more contestable?

\section{ANTITHESIS: TRADITIONAL RELIGION}

According to Emile Durkheim, most actual believers "feel that the real function of religion is not to make us think, to enrich our knowledge, nor to add to the conceptions which we owe to science others of another origin and another character, but rather, it is to make us act, to aid us to live". He also acknowledges that religion "is not merely a system of practices - but also a system of ideas whose object is to explain the world". ${ }^{13}$ But the primary purpose of "religion", in its broadest sense, is rather to inspire than to explain.

The believer who has communicated with his god is not merely a man who sees new truths of which the unbeliever is ignorant; he is a man who is stronger. He feels within him more force, either to endure the trials of existence, or to conquer them. It is as though he were raised above the miseries of the world, because he is raised above his condition as a mere man; he believes that he is saved from evil, under

${ }^{13}$ Emile Durkheim, The Elementary Forms of the Religious Life: A Study in Religious Sociology, tr. J.W. Swain (London: Allen \& Unwin, 1915), p. 428. 
whatever form he may conceive this evil. The first article in every creed is the belief in salvation by faith.

To cultivate and maintain that faith we need the cult:

Whoever has really practised a religion knows very well that it is the cult which gives rise to these impressions of joy, of interior peace, of serenity, of enthusiasm which are, for the believer, an experimental proof of his beliefs. The cult is not simply a system of signs by which the faith is outwardly translated; it is a collection of the means by which this is created and recreated periodically. Whether it consists in material acts or mental operations, it is always this which is efficacious. ${ }^{14}$

Faith is not credulity. It is the repeated invocation of a sustaining spirit through cultic practices, a spirit no less efficacious for being, perhaps, imaginary. The cultic practices themselves may have a natural origin: we don't need a religious education to find it natural to rouse, for example, a spirit of righteous anger by stomping up and down and shouting. Nor do we need romantic comedies to learn how to encourage ourselves and others to season our lusts with humour. But common practices and artistry play a role in channelling our spirits into particular forms, and may also offer doctrines to believe in, doctrines that may last longer than the first emotions. The doctrines flow from the rituals, and the rituals from the emotions, but doctrines then influence rituals, and rituals the emotions. The development of Christian doctrine in its early centuries was guided by the practice of the worshipping community: because Christians felt the figure of Jesus animated in their rituals they were compelled to conclude that Jesus must be the Word of God. He was present to them in the stories they exchanged, and in the breaking of bread together. The Councils that left us the strange doctrines, of Christ's two natures, and the divine Trinity, were not engaged in abstract theological reflection for its own sake (though doubtless some theologians were), but seeking to give a memorable account of the story they and other believers were enacting daily, weekly, and over the ceremonial year.

This is not the end of the story. The Christian religion (or any other serious creed) is not only a verbal counterpart of cultic practices, and these are not followed only to keep our spirits up. Tertullian was quite right to insist that there were good reasons actually to believe the doctrines, the more firmly because they were so odd that no-one would

${ }^{14}$ Durkheim, op.cit., pp. 416-17. 
have propounded them unless there were: "natus est Dei Filius: non pudet quia pudendum est; et mortuus est Dei Filius: prorsus credibile est, quia ineptum est; et sepultus resurrexit: certum est, quia impossibile". ${ }^{15}$ There were many easier ways of preaching the Gospel: if the early Church settled on these particular doctrines it was at least not the easier option.

But nowadays it is better to start with the emotive, affective aspects of religion, if only to avoid laborious and pointless exchanges about the Spaghetti Monster. God isn't an entity like that, one that might or might not "exist", against a natural background. The question can also be addressed metaphysically, as it is by MacIntyre:

To believe in God is not to believe that in addition to nature, about which atheists and theists can agree, there is something else, about which they disagree. It is rather that theists and atheists disagree about nature as well as about God. For theists believe that nature presents itself as radically incomplete, as requiring a ground beyond itself, if it is to be intelligible, and so their disagreement with atheists involves everything. ${ }^{16}$

This is clearly correct, but the first step is more easily taken through the emotive or ethical aspects of theism. "Believing in God" or at least the God of Abraham, whatever else it is, is a commitment to the possibility and eventual success of Justice. Believers bind themselves to a cause, and nourish their commitment by reciting and acting out the stories that give weight and sense to it - which is not simply to the present order of society, but to an hypothesized ideal: to do justice and love mercy. Marx was right at least in this: "Religion is the sigh of the oppressed creature, the heart of a heartless world, and the soul of soulless conditions. It is the opium of the people." 17 The point of religion, or religion of the mainstream Abrahamic sort, is not to reconcile us to iniquity, but to remind us of an alternative. A belief in God's Omnipotence does not necessarily require that we believe that everything that now happens is His Will, but that His Will shall prevail, His Kingdom come. 'Magna est veritas, et praevalebit.'

${ }^{15}$ Tertullian, De carne Christi, 5.4, after Aristotle: see James Moffat, 'Aristotle and Tertullian' in Journal of Theological Studies 17 (1916), pp. 170-1, pointing to Aristotle, Rhetoric, 2.23,22: there are some stories so improbable in themselves that no one would have invented them. See also Robert D. Sider, 'Credo quia Absurdum?', in Classical World 73 (1980), pp. 417-9.

16 Alasdair MacIntyre, God, Philosophy, Universities: A History of the Catholic Philosophical Tradition (London: Rowman \& Littlefield, 2009), p. 47.

${ }^{17}$ Karl Marx, 'Introduction' to The Critique of Hegel's Philosophy of Right, ed. Joseph O’Malley (Cambridge: Cambridge University Press, 1970; $1^{\text {st }}$ published 1843-4). 
Believing in the Divine Trinity is believing in the possibility and hope of love, the community of the holy ones.

May not Christians ... be allowed to believe the divinity of our Saviour, or that in Him God and man make one Person, and be verily persuaded thereof, so far as for such faith or belief to become a real principle of life and conduct? inasmuch as, by virtue of such persuasion, they submit to His government, believe His doctrine, and practise His precepts, although they form no abstract idea of the union between the divine and human nature; nor may be able to clear up the notion of person to the contentment of a minute philosopher. ${ }^{18}$

This interpretation of doctrine seems easier in "primitive" religions. Raising sceptical doubts about the actors who don ceremonial masks to impersonate or represent the many gods of popular Hindu religion, or Voodoo, or the Australian Dreamtime, looks much like the crasser forms of Christian missionary endeavour. It would be like telling Star Trek enthusiasts that there is no Federation, or that Vulcans and Earthhumans could not possibly interbreed. It is more easily assumed that even Star Trek enthusiasts know that very well, and that even "primitive polytheists" are aware that they are acting.

And why not? The very thing that makes us human is our imaginative capacity, our talent and our desire for imaginative fictions that can gather up our manifold experience, offer engaging characters and plots for ourselves to take on board, and unite into a single story people who might otherwise be enemies. Unlike other animals - or what we conceive to be true of other animals - we each live within at least two worlds: the world of ordinary sensibilia, and the world of imagination. Sometimes that imagined world so permeates the sensible that we see no difference. Sometimes we can convince ourselves that the imagined world is more real than the sensible. The epic of an expanding universe, dark matter, black holes and supernovas sprinkling the elements of life around the galaxies impresses us as "real", even though we mostly pay no attention at all to it. We may be the more easily persuaded that traditional religion teaches truth precisely because the gods it imagines are obviously present with us, in ordinary life as well as ritual. No one can seriously doubt the reality of Aphrodite, or Ares, or Apollo, whether they are gods or demons

${ }^{18}$ George Berkeley, Alciphron (Euphranor speaks), in Works of George Berkeley, eds., A.A. Luce \& T.E. Jessop (Thomas Nelson: London, 1946-57), vol.3, p. 298. 
or allegorical fictions. Poets and fantasists nowadays don't invent new gods, but they do invent characters and superheroes, which then become common stock for individual and collective fantasy. We know very well that Sherlock Holmes, James Bond and Wonder Woman "don't exist", any more than Santa Claus or Terry Pratchett's Death. But we also know that these characters are influential, and can be invoked to structure our personal motives. It is pointless, naïve, absurdly literal-minded, to complain about an author's inconsistencies, or creative attitude to history - unless the critic is cooperating in creating the imagined world, or unless she has her own commitments to a different theme than the author's. In either case the point would not be to insist that the created world is at odds with "reason", or is not "realistic". Artists, authors and the founders of religions are expanding our imaginative experience. Whether we are inspired to join them in their endeavour, or to denounce them in whatever terms we wish, is not a matter for reason to decide, but imagination and desire.

\section{SYNTHESIS: RADICAL OR MYSTICAL RELIGION}

Sociological analysis of "religion" has usually suggested that the rituals and stories serve to maintain the actual social order, and even that God or the gods are idealized versions of that order. "Really" we are all just worshipping our collective selves. There is probably some truth in this. The powerful will always seize on whatever story helps them to maintain their power, and suppress whatever story or ceremonial may remind us of alternatives. They may even adopt and reconstruct the very rites and creeds that once enabled a rebellion against an older order, and sincerely (or self-deceivingly) imagine that they themselves are the stuff of which rebels and martyrs are made. Modern Western atheism itself can be interpreted as just such a revolt against established gods - a revolt that has now been co-opted to secure the State against any thought of a rival. Modern atheists often sound much more like Inquisitors than Martyrs, and it is easy to suspect that they would indeed have been Inquisitors in an earlier age, self-assured in their own stories but fearful of the opposition. And of course - to spread the critical comments round - the early Christian Church, which was once deemed atheistical precisely because it would not acknowledge the established gods, learnt rather too well the mechanisms of control that had been used against it. 
It is nonetheless important for unbelievers and believers alike to recall the mainstream Abrahamic message:

Follow a light that leaps and spins,

Follow the fire unfurled!

For riseth up against realm and rod,

A thing forgotten, a thing downtrod,

The last, lost giant, even God,

Is risen against the world. ${ }^{19}$

Chesterton associated this aspect of religion specifically with the Christian tradition:

That a good man may have his back to the wall is no more than we knew already; but that God could have his back to the wall is a boast for all insurgents for ever. Christianity is the only religion on earth that has felt that omnipotence made God incomplete. Christianity alone has felt that God, to be wholly God, must have been a rebel as well as a king. Alone of all creeds, Christianity has added courage to the virtues of the Creator. For the only courage worth calling courage must necessarily mean that the soul passes a breaking point - and does not break..$^{20}$

Jewish tradition is not that far from the thought, supposing that God suffers along with His people and sustains them through that suffering. The strange Christian development of the theory rests on the idea that an invulnerable God can't suffer along with us unless He could somehow also suffer in His own person. ${ }^{21}$ On the one hand, God cannot face destruction; on the other, yes, He can.

Neither the Abrahamic nor the Buddhist religious tradition can be satisfied simply with the social and mythological order we have inherited. Both include in their founding myths the idea that we should leave those orders, and cannot always rely on traditional authority. As Berkeley said:

In our nonage while our minds are empty and unoccupied many notions easily find admittance, and as they grow with us and become familiar to our understandings we continue a fondness for them.... But we would do well to consider that other men have imbibed early notions, that they as

${ }^{19}$ G.K. Chesterton, Collected Poems (London: Methuen, 1950), p. 268.

${ }^{20}$ G.K. Chesterton, Orthodoxy (Chicago: Moody Press, 2009; $1^{\text {st }}$ published 1908), p. 206. Hindus, of course, have the story of Krishna to remind them that a god could live through the same catastrophes as harass us, and die by accident. But Krishna does not clearly submit Himself to human law, nor yet experience defeat.

${ }^{21}$ See Peter Geach, Providence and Evil (Cambridge: Cambridge University Press, 1977). 
well as we have a country, friends, and persons whom they esteem. These are pleas which may be made for any opinion, and are consequently good pleas for none. ${ }^{22}$

At the same time, we have to make a start from somewhere, and tradition gives us that beginning: "if we were left, every one to his own experience, [we] could know little either of the earth itself or of those things the Almighty has placed thereon: so swift is our progress from the womb to the grave". 23 There is a further problem, about the ordering of our lives together.

There must ... of necessity, in every State, be a certain system of salutary notions, a prevailing set of opinions, acquired either by private reason and reflection or taught and instilled by the general reason of the public, that is, by the law of the land. ... Nor will it be any objection to say that these are prejudices; inasmuch as they are therefore neither less useful nor less true, although their proofs may not be understood by all men. ... The mind of a young creature cannot remain empty; if you do not put into it that which is good, it will be sure to receive that which is bad. Do what you can, there will still be a bias from education; and if so, is it not better this bias should lie towards things laudable and useful to society? ... If you strip men of these their notions, or, if you will, prejudices, with regard to modesty, decency, justice, charity, and the like, you will soon find them so many monsters, utterly unfit for human society. ${ }^{24}$

If we can manage to believe that tradition at least contains a valuable starting point, we can also learn to correct it. If it is merely the product of chance variation and natural selection for reproductive advantage it seems difficult to see why we should trust it, or our individual reasonings, even so much. A merely naturalistic, "unbelieving", account of the world and human history can hardly avoid despair. "What beauty can be found in a moral system, formed, and governed by chance, fate or any other blind, unthinking principle?" ${ }^{25}$ I do not mean that unbelievers must all, pejoratively, be infidels. On the contrary, I am arguing that we do

${ }^{22}$ Berkeley, 'Sermon on Religious Zeal' (1709-12), in Works, op.cit., vol. 7, p. 20. See also my 'Berkeley's Philosophy of Religion', in Kenneth Winckler ed., Cambridge Companion to Berkeley (New York: Cambridge University Press, 2005), pp. 369-404.

${ }^{23 .}$ Berkeley, 'Sermon on Immortality', in Works op.cit., vol. 7, p. 14.

24. Berkeley, 'Discourse to Magistrates', in Works op.cit., vol. 6, pp. $203 \mathrm{f}$

${ }^{25}$ Berkeley, Alciphron (Euphranor speaks), in Works op.cit., vol. 3, p. 128. See also E.O. Wilson on our moral feelings as a "hodge podge" of evolutionary adaptations, which we could some day reorganize, without any better goal than to keep our line alive: On Human Nature (Cambridge, Mass: Harvard University Press, 1978), p. 196. 
not depend for our happiness on reason, and even atheists who pride themselves on being "Bright" are as irrational as any. One of Buddha's sermons offered the image of an enormous mountain that was irreversibly advancing on us all. If this were so, he enquired, would we not be seeking some way to escape? And yet, there is exactly such a mountain coming: not merely our own individual deaths, but the deaths of everyone and everything we love, an absolute destruction of all we might achieve. ${ }^{26}$ And yet we all ignore this fact in almost every moment of our lives together. Some modern transhumanists sketch out both near-future and far-future stories in which we and our craft-enhanced descendants remake the worlds. Some even acknowledge that they are offering a naturalized religion, a technological realization of the opium dream. ${ }^{27}$ There can be no present proof that these futures would be either possible or desirable: they are commitments that go far beyond the evidence. The difference between the transhumanist and the older believer is the moral that they draw: the older believer, hoping to be caught up into the dance of immortal love, concluded that we must seek to act and imagine as that dance requires. In short, that we need to love one another, and see the god or the god-to-be in each of us. The transhumanist moral is rather that we must seize the present opportunity for physical and biological research, and keep the research grants coming! ${ }^{28}$

One other response to the advancing mountain is simply to forget it. Our error, it may be said, is always to be living outside the present, in hope or fear or desperate depression. Thus an old story, first seen in the Mahabharata, is gradually turned into advice to "gather rosebuds while ye may": ${ }^{29}$

A man travelling across a field ecountered a tiger. He fled, the tiger after him. Coming to a precipice, he caught hold of the root of a wild vine and swung himself down over the edge. The tiger sniffed at him from above.

${ }^{26}$ As Bertrand Russell, rather pompously, reminded us in Mysticism and Logic (London: Longmans, Green \& Co., 1918), p. 56. Logan Pearsall Smith mocked the rhetoric in All Trivia (London: Constable \& Co., 1933), p. 81. See also my From Athens to Jerusalem: the Love of Wisdom and the Love of God (Oxford: Clarendon Press, 1984), pp. 12-13.

${ }^{27}$ See 'Deep Time: does it matter?' in George Ellis, ed., The Far-Future Universe (Radnor, Pennsylvania: Templeton Foundation Press, 2002), pp. 177-95.

${ }^{28}$ See Frank J. Tipler, The Physics of Immortality: Modern Cosmology, God and the Resurrection of the Dead (New York: Doubleday, 1994).

${ }^{29}$ Robert Herrick, 'To the Virgins, to make much of time' (1648): Arthur QuillerCouch, ed., The Oxford Book of English Verse: 1250-1900 (Oxford: Clarendon Press, 1939), p. 274 (that is, get laid before it is too late). 
Trembling, the man looked down to where, far below, another tiger was waiting to eat him. Only the vine sustained him. Two mice, one white and one black, little by little started to gnaw away the vine. The man saw a luscious strawberry near him. Grasping the vine with one hand, he plucked the strawberry with the other. How sweet it tasted! ${ }^{30}$

The original point of the story was rather to point out how easily we are distracted, and to suggest that we should regard all these dangers and delights - but especially the delights - as unimportant, and set ourselves to escape. Even the "presentist" moral is a lot more difficult to act upon than any simple injunction to eat, drink and be merry: we cannot afford to dull our senses and imagination if we are even to enjoy the moment. And the original moral is still stranger if there could really be no way out. The secular interpretation of the story, so to speak, is also very easy to mock:

It's really impressive the way modern psycho-analysis has confirmed the insights of the New Testament. Where two or three are gathered together, you know. It is an indisputable fact that groups of people, huddled together as closely as possible, do feel warmer. That is the basis of Group Therapy. It is also known as the Kingdom of Heaven. ${ }^{31}$

Celia Green's sardonic comment is set in a dream-world where "sensible people" can think of nothing better to do than reconcile themselves and others to a frozen, barren landscape. Her response, in the dream, is simply to wake up!

Waking Up is indeed an important metaphor if we are ever to understand the life of faith. ${ }^{32}$ Respectable philosophers in the past have agreed that this life, this world, is a dream and a delirium from which we should gladly wake. ${ }^{33}$ Plotinus noted that such waking would most likely be disbelieved when we drop off to sleep again. ${ }^{34}$ This world here-now

${ }^{30}$ Paul Reps, Zen Flesh, Zen Bones (Tuttle: Boston, 1957), p. 39; cf. Mahabharata Bk. 11, pp. 5-6; The Lalitavistara Sütra: The Voice of the Buddha, the Beauty of Compassion, tr. Gwendolyn Bays (Berkeley: Dharma Publishing, 1983). See Helen B. Holt/Karma Sangye Khandro, 'Honey or Nectar': URL = <http://www.khandro.net/nature_honey. htm $>$ (accessed 28th April 2011) for a brief account of the story's transmutations.

${ }^{31}$ Celia Green, The Human Evasion (London: Hamish Hamilton, 1969), p. 124.

${ }^{32}$ I began examining it in 'Waking-up: a neglected model for the After-life': Inquiry 26 (1983), pp. 209ff, and have addressed the issue periodically since then, See especially Understanding Faith: Religious Belief and its Place in Society (Exeter: Imprint Academic, 2009), pp. 158-71.

${ }^{33}$ Marcus Aurelius, Meditations 2.17.1.

${ }^{34}$ Plotinus, Ennead V.5 [32].11. 
is not the real world. So Chesterton was perhaps not quite correct: it is not after all a sure mark of sanity to think we are awake already. He may still have been right to suggest that we should take the dream seriously. "Whether it's reality or a dream, doing what's right is what matters. If it's reality, then for the sake of reality; if it's a dream, then for the purpose of winning friends for when we awaken." ${ }^{35}$ And perhaps it is easier to "do what's right" if we remember that material gains are fairy gold, that vanish on our waking.

But if this world and our experience of it are relatively dream-like, and real causes, real destinies, real effects are "outside over there", we cannot expect to discover this simply from the dream itself. Perhaps, by sounder standards, our dream experience is implausible or incoherent, but we don't have access to those standards: whatever the dream shows us we will take as "normal" - at least until we begin to wonder at what happens and its curious incongruities, its failure to be what something in us still demands. It is that strange feeling, not unlike what Joad called "the still, small voice that whispers 'fiddlesticks"' 36 , that offers the first challenge to conventional reason, and to consensus reality.

We ... have dreamt the world. We have dreamt it as firm, mysterious, visible, ubiquitous in space and durable in time; but in its architecture we have allowed tenuous and eternal crevices of unreason which tell us it is false. ${ }^{37}$

Conversely, once one has concluded that this world is a dream there is nothing the unbeliever can do to prove one wrong! If one shouldn't believe anything without "sufficient" evidence it is not clear which belief it is from which we should withhold consent. A mere feeling or conviction is not proof of a kind that any court or council or laboratory team should countenance: but in that case, why should a mere feeling of "reality" - which neurophilosophers tell us is engendered in the brain, and could be engineered - be judged sufficient to exclude the possibility that we are dreaming, and that we might yet wake? That thought too, no doubt, can be induced - and maybe much "religious" ritual, much

${ }^{35}$ Pedro Calderón de la Barca, Life's A Dream (Boulder, Colorado: University Press of Colorado, 2004; $1^{\text {st }}$ published as La vida es sueño in 1635), p. $137 \mathrm{f}$ (Sigismund speaks).

${ }^{36}$ G.E.M. Joad The Untutored Townsman's Invasion of the Country (London: Faber, 1946), p. 224. The remark is also attributed to W.K. Clifford: this is not impossible, but I have not located any context.

${ }^{37}$ J.L. Borges, 'Avatars of the Tortoise' in Labyrinths ed. D. A. Yates and J. E. Irby (Harmondsworth: Penguin, 1970), pp. 202-8. 
religious art and architecture, is aimed, exactly, at inducing it. So Abbot Suger declared of the abbey church of St.Denis, in the twelfth century, that there he felt himself "dwelling in some strange region of the universe which neither exists entirely in the slime of the earth nor entirely in the purity of heaven, and that by the grace of God, [he could] be transported from this inferior to the higher world in an anagogical manner" ${ }^{38}$ Of course we aren't all moved by the very same rituals, stories or places. The best that we can manage, probably, is a diversity of belief: let people follow whatever lights they see, even if some turn out to be merely marsh-lights (or the Puck).

No one takes hold of the world immediately; between the two there imposes speech, the language of society, the inherited store of concepts and images.... It is by the multiplication of ways of talking that we attain the plenitude of plenitudes. ${ }^{39}$

But we still need faith to carry on our own particular journey, and would feel easier in our minds if we could identify some generally plausible criterion for picking our direction, and some sketchy idea of what the world should be if our journey is to be a hopeful one. What signs might we encounter that would confirm our choice, or send us another way? If this world here-now is indeed a dream how shall we wake, and what will the waking world turn out to be?

Our country from which we came is There, our Father is There. How shall we travel to it, where is our way of escape? We cannot get there on foot; for our feet only carry us everywhere in this world, from one country to another. You must not get ready a carriage, either, or a boat. Let all these things go, and do not look. Shut your eyes, and change to and wake another way of seeing, which everyone has but few use. ${ }^{40}$

Both rational and traditional religion are mainly concerned to help us live here-now, to give us the intellectual and emotional strength to carry on. We live with inconsistencies. Truth may indeed, as Boethius hoped, be "one, without a flaw"

${ }^{38}$ E. Panofsky ed., Abbot Suger on the Abbey Church of St.-Denis (Princeton: Princeton University Press, 1945), p. 65.

${ }^{39}$ A. Lacy, Miguel de Unamuno: the Rhetoric of Existence (The Hague: Mouton \& Co., 1967), p. 124, paraphrasing Unamuno.

${ }^{40}$ Plotinus, Ennead I.6 [1].8.

${ }^{41}$ Boethius, Consolation of Philosophy: Medieval Latin Lyrics, tr. Helen Waddell (Harmondsworth: Penguin, 1952; $1^{\text {st }}$ published 1929), p. 59. 
single, singular truth. We are all, initially, polytheists, acknowledging many different and conflicting demands on our reason, time and energy, and merely hoping that the conflicts will not tear us quite apart. No single ideal that we conceive will reconcile the differences within us and between us: indeed, the more vociferous the advocates of some one way of seeing the more they engender conflict and reprisals - a lesson that some modern atheists would do well to learn. Chesterton's most eloquent argument for the primacy of the Catholic Church was that it had, he thought, managed to harness many different impulses and partial truths, allowing the lion, as it were, to lie down with the lamb without demanding that he not be a lion. ${ }^{42}$ The best that most of us can manage is to serve our partial ideals, our partial truths, without denying that others have partial truths as well, or neglecting the truths we own - which is itself a working contradiction!

So does "religion" give us any clues to follow? The greatest, most seminal figures of our religious history are those who renounced "the world", whether by literally abandoning all their this-worldly concerns, what to eat or drink or wear, or at least by refusing any this-worldly honours. Even their disciples did almost as much. One of Plotinus's disciples, for example, the Roman Senator Rogatianus, "gave up all his property, dismissed all his servants, and resigned his rank. ... He only ate every other day." ${ }^{33}$ Renunciation, turning away from the temptations of the dream, was at least a preparation for the day when we wake up. For some, it may have been an actual awakening. It is unsurprising that any messages they then brought back to the dreamers seems "unreasonable". It is, after all, the dream that dictates to the rest of us what we consider reason.

Plotinus recognized truths which we, whether we will or not, must call revelations, which are entirely strange to the modern consciousness and even excite the highest degree of indignation. And now the main point: when Plotinus had to decide between "revealed" and "natural" truths, he unhesitatingly took the side of the former: "that which appears most real to common consciousness has the least existence". ${ }^{44}$

${ }^{42}$ Chesterton, Orthodoxy, op.cit., p. 148 after Isaiah 12.6.

${ }^{43}$ Porphyry, Life of Plotinus, 7.32-40: Plotinus, tr. A.H. Armstrong, vol.1 (London: Loeb Classical Library, Heinemann, 1966), p. 27.

${ }^{44}$ Lev Shestov, In Job's Balances, tr. Camilla Coventry and C.A. Macartney, ed. Bernard Martin (Ohio: Ohio University Press, 1975), Pt. 3 'Plotinus's Ecstasies', after Ennead, V.5 [32].11: URL $=<$ http://shestov.by.ru/ijb/jb_0.html> 
Plato had said the same - that the prisoner released from his chains and brought up into the light would at first be dazzled, and would find his fellow prisoners wholly unbelieving of his revelation if he were to go back down into the cave. ${ }^{45}$ Why should we believe him? Why should we not? If it is wrong, as rationalists hold, to believe what someone tells us, without the blessing of "reason", it must also be wrong to go on believing what we already do, without the blessing of "reason".So which prophet shall we follow? You and I here-now are unlikely ourselves to abandon property and rank and family to practise extreme austerities (or even minor ones). Religious traditions that demand that everyone renounce the world in just that way don't usually, it seems, survive! We can hope that there will be a place in the Kingdom for such householders and fairly honest citizens as do not take the unfamiliar road. But we may still also hope for some words from, as it were, the athletes of the spirit. Shall we read the Buddha's sermons, or the Desert Fathers? Shall we hope for our sense of self to be dissolved, and a subsequent unveiling of the Unborn and Indestructible without which, so the Buddha taught us, there could be no escape from Here ${ }^{46}$ Or shall we hope instead to recall our higher selves, and rejoin the dance of immortal love, as pagan Platonists like Plotinus hoped? Or follow the Incarnate Word, as Christians should? Or imagine a transhumanist utopia at the end of time (an event indefinitely delayed)? ${ }^{47}$ How different in actual practice are the claims? The many different forms and recipes of consciously unreasonable religion may offer us too many choices: how can we sensibly choose, when the very criteria for choice are determined by the choice we shall have made? And if there is no reasonable choice, in that sense, must we not - logically - conclude that we must make unreasonable choices? We cannot avoid

\footnotetext{
${ }^{45}$ Plato, Republic, 7.514a-518b.
}

46 "There is, monks, an unborn - unbecome - unmade - unfabricated. If there were not that unborn - unbecome - unmade - unfabricated, there would not be the case that emancipation from the born - become - made - fabricated would be discerned. But precisely because there is an unborn - unbecome - unmade - unfabricated, emancipation from the born - become - made - fabricated is discerned": Khuddaka Nikaya (Collection of Little Texts), Bk. 3 Udana (Exclamations) 8:3: 'Nibbana Sutta: Total Unbinding (3)', tr. Thanissaro Bhikkhu Access to Insight, 8 July 2010, URL $=<$ http://www.accesstoinsight. org/tipitaka/kn/ud/ud.8.03.than.html $>$ (accessed 29th April 2011).

${ }^{47}$ See Freeman J. Dyson, 'Time without End: Physics and Biology in an Open Universe': Reviews of Modern Physics, 51.3 (1979), reprinted in Selected Papers of Freeman Dyson (Providence, Rhode Island: American Mathematical Society, 1996), pp. 529-42; URL = $<$ http://www.aleph.se/Trans/Global/Omega/dyson.txt> (accessed 29th April 2011). 
the choice: whatever happens we will have walked a particular path through life, without any prior proof that ours is the one right way. Nor is anything gained by appealing to any supposedly infallible authority, whether papal or scientific: "of what use is an infallible guide without an infallible sign to know him by?" 48 We must end by hoping that "in every Humane Creature there is a ray of common sense, an original light of reason and nature which the worst and most bigoted education, although it may impair, can never quite extinguish" ${ }^{49}$

And so I end at my beginning: the light of reason, properly understood, must be our guide - but that light is neither to be equated with my own individual conviction ${ }^{50}$ nor yet with consensus reality. Neither I nor We determine what is true, but the Truth, if we are not wholly to despair, must still be somehow in us. Our commitment must always be to the Truth itself, and not just to our best image of that Truth, although we cannot thus be committed to the Truth except by following our best image, while still being ready to be deprived of it. This is the final paradox of reason; that our goal, the Good, must lie beyond both intellect and being. ${ }^{51}$ And Intellect is most itself "when it goes out of its mind 'drunk with the nectar'; then it falls in love, simplified into happiness by having its fill, and it is better for it to be drunk with a drunkenness like this than to be more respectably sober". ${ }^{52}$ That Intellect is indistinguishable from Faith, and that Faith is God. ${ }^{53}$

${ }^{48}$ Berkeley, 'Letter to Sir John James', in Works op.cit., vol. 7, p. 148.

${ }^{49}$ Berkeley, 'Primary Visitation Charge', in Works op.cit., vol. 7, p. 163.

${ }^{50}$ That would then be "an inward conceited principle ... sufficient to dissolve any human fabric of polity or civil government": Berkeley, 'Discourse to Magistrates', in Works op.cit., vol. 6, p. 217.

${ }^{51}$ Plato, Republic, 6.509b.

${ }^{52}$ Plotinus, Ennead, VI.7 [38].35.

${ }^{53}$ See Aristotle, Metaphysics, 12.1072b28. 